ISSN 2078-6441. Вісник Львівського університету. Серія географічна. 2013. Випуск 44. С. 265-274. Visnyk of the Lviv University. Series Geography. 2013. Issue 44. P. 265-274.

631.445.4:631.41(477.83+477.82)

\author{
гор пішII \\ ввівський н ціон льний університет імені в н \\ вул. . орошенк , 41, 79000, м. ввів, кр їн
}

ведено д ні щодо в лового хімічного скл ду чорноземів опідзолених і типових ок льсько- орчинської п смової височини. иявлено геогр фічні особливості формув ння морфологічного профілю чорноземів олинської височини. пис но зв'язок між різними генетичними підтип ми чорноземів т хімічним скл дом їхньої силік тної ч стини. изн чено культурну скл дову грунтоутворення у формув нні морфологічного профілю чорноземів глибоких тер сових місцевостей олинського обужжя.

лючові слов : чорнозем, в ловий хімічний скл д, будов грунтового профілю, морфологічні озн ки, культурн еволюція грунтів.

икорист ння грунтів ок льсько- орчинської п смової височини у сільськогоспод рських цілях відоме зд вн . гумусовому горизонті чорноземів олинського обужжя ч сто н явні включення- ртеф кти (фр гменти кер міки, предметів з дерев і мет лу) різного історичного ч су, що підтверджують трив лість їхньої культурної еволюції. езрівнянно коротшою є історія н укових досліджень чорноземів олинської височини.

прикінці ст. великий н уковий резон нс м ли дослідження лесовогрунтового покриву олинської височини, з поч тков ні . утковським [9]. ін першим зробив п леогеогр фічну реконструкцію плейстоцен-голоценового педогенезу н лесоподібних суглинк х цього регіону. рунтовний опис морфології чорноземів

хідноукр їнського кр ю н ведений у моногр фії . убер “ лицько- олинські чорноземи, їхнє утворення і природні вл стивості” [10]. ж ль, втор про н лізув в тільки чорноземи г лицько-подільських земель, не визн чивши особливостей формув ння чорноземів суміжних територій, зокрем олинської височини. г льні відомості про природу олинського обужжя, у тому числі його грунтовий покрив, є в пр цях укр їнських геогр фів міжвоєнного (1920-1939) періоду, зокрем проф. . ередіїв [9]. і пр ці м ють перев жно описовий х p ктер і цік ві з погляду геогр фії грунтів кр ю, особливостей їхнього господ рського використ ння.

овим поштовхом до вивчення грунтового покриву олинської височини ст ли великом сшт бні грунтово-к ртогр фічні дослідження 1957-1961рp. і под льші ет пи 3 коригув ння м тері лів цих досліджень. ході досліджень з'ясов но дет лі геогр фії чорноземів (м сшт б грунтового знім ння 1:10 000), опис но їхні морфологічні, з г льні фізичні, фізико-хімічні й грохімічні вл стивості.

з г льних рис х грунтовий покрив досліджув ної території вивчений досить добpe. ін опис ний у н укових публік ціях і моногр фіях відомих укр їнських грунтозн вців і фізико-геогр фів $[1,2,5-7]$. ондові й літер турні м тері ли по чорнозем х

(C) піш ., 2013 
олинської височини є доброю ст ртовою площ дкою для фунд мент льних досліджень структури грунтового покриву, глибокого вивчення природи орг нічної і мінер льної речовини грунтів, еволюції чорноземів хідноукр їнського кр ю.

енетичний н ліз профілю чорноземів неможливий без д них спеці льних н лізів, зокрем в лового хімічного скл ду їхньої силік тної ч стини. перув ння пок зник ми вмісту основних оксидів $\left(\mathrm{SiO}_{2}, \mathrm{Al}_{2} \mathrm{O}_{3}, \mathrm{Fe}_{2} \mathrm{O}_{3}, \mathrm{CaO}, \mathrm{MgO}, \mathrm{K}_{2} \mathrm{O}, \mathrm{Na}_{2} \mathrm{O}, \mathrm{P}_{2} \mathrm{O}_{5}, \mathrm{SO}_{3}\right)$ у профілі чорноземів ок льсько- орчинської п смової височини відкрив є шлях для дослідження грунтів н рівні елемент рних грунтових процесів, д є змогу визн чити вз ємозв'язок між ними і з н прямом грунтоутворного процесу, специфікою генези чорноземів, своєрідністю їхніх хімічних вл стивостей, виявити суч сні тенденції грогенної і пост грогенної еволюції грунтів.

суч сному укр їнському грунтозн встві історико-генетичного н пряму досліджень чорноземів олинського обужжя, як і хідноукр їнського кр ю $з$ г лом, пр ктично нем . ершопричиною цього є відчутний дисб л нс у з безпеченні основних скл дових н літичної б зи чорноземів. елик кількість д них з г льних грунтових н лізів (вміст з г льного гумусу, гр нулометричний скл д, 3 г льні фізичні, фізико-хімічні і грохімічні пок зники) не покрив ється необхідною кількістю д них спеці льних н лізів (групового і фр кційного скл ду гумусу, мікроморфологічного, в лового хімічного і рентгендифр ктометричного н лізів). собливу роль відігр $\epsilon$ дослідження силік тної ч стини грунтів, іiї тонкодисперсної мулистої фр кції. процесі звітрюв ння і грунтоутворення у ній трив лий ч с н копичуються з лишкові продукти педогенезу, в яких зберіг ється генетичн інформ ція про історію формув ння профілю чорноземів, спрямов ність їхньої пізньоголоценової еволюції.

сновне з вд ння - розширення н літичної б зи д них чорноземів н лесоподібних суглинк х ок льсько- орчинської п смової височини 3 метою генетичної реконструкції умов і процесів формув ння їхнього профілю, ді гностики і кл сифік ції чорноземів.

ля дослідження в лового хімічного скл ду чорноземів серед зн чної кількості н лізов них розрізів вибр но репрезент тивні грунтові об'єкти, шо сформув лись н різних геоморфологічних поверхнях: чорноземи опідзолені і типові полого-хвилястих вододільних пл то, т кож тер сових місцевостей долини хідного угу. ідготовк грунтових зр зків викон н н к федрі грунтозн вств і геогр фії грунтів ьвівського н ціон льного університету імені в н дослідження чорноземів з стосов но комплекс з г льних і спеці льних методів кількісного н лізу грунтів. ловий хімічний н ліз чорноземів викон ний у хімічній л бор торії нституту геології і геохімії горючих корисних коп лин кр їни.

меж х ок льсько- орчинської п смової височини н міжп смових рівнин х $\mathrm{i}$ розлогих зниженнях, придолинних схил х, укритих з поверхні лесоподібними суглинк ми ередньоруської лесової провінції, сформув лись перев жно чорноземи опідзолені регр дов ні і чорноземи типові неглибокі м логумусні. они є н йродючішими грунт ми регіону, чим зумовлен його сільськогоспод рськ спеці ліз ція. йбільш площ чорноземів приурочен до бузького природного р йону ок льського п см (близько $62 \%$ від його з г льної площі) [1].

ериторі льн приуроченість чорноземів м є вир зну геоморфологічну першопричину. ельєф місцевостей лівобережної ч стини б сейну хідного угу, у меж х бузького природного р йону, є дещо піднятий н д пр вобережною ч стиною ок льсько- орчинської п смової височини, проте він водноч с і більш рівнинний. ут 
м йже нем є великих пл корних лісових м сивів, як н пр вобережжі хідного угу [6]. грунтовому покриві підвищених ч стин пл то домінують темно-сірі лісові грунти і чорноземи опідзолені (перев жно регр дов ні), н широких міжп смових полого-Хвилястих рівнин х 3 вищим рівнем 3 ляг ння грунтових вод - чорноземи типові неглибокі і середньоглибокі м логумусні. орноземи олинської височини, особливо чорноземи типові, м ють низку морфологічних вл стивостей, відмінних від н логів н решті території лісостепової зони кр їни. ричиною цього є особливості розвитку природи олинського кр ю в голоцені. ля підтвердження н ведемо стислий опис н йбільш х р ктерних озн к їхньої морфології.

орфологічн будов профілю чорноземів опідзолених сильно регр дов них глеюв тих грубопилув то-легкосуглинкових н лесоподібних суглинк х бузького природного р йону ок льського п см предст влен розрізом ойсл вичі -5, 3 кл деним н відст ні 800 м південніше с ойсл вичі ок льського р-ну ьвівської обл. езорельєф - рівн ділянк широкої вододільної поверхні з розвиненим мікроз п динним рельєфом. гіддя - рілля (пшениця). кип ння від $10 \% \mathrm{HCl}$ з 40 см. умусовий горизонт з г льною потужністю 70 (78) см із язикув тою формою нижньої межі. орфологічні озн ки кислотного руйнув ння силік тної ч стини профілю у формі кремнеземистої присипки помітні тільки після підсих ння грунту. идимих озн к ілювіюв ння глини у формі кут н пр ктично нем є бо вони сильно з ву льов ні. ередня ч стин профілю сильно кротовинн 3 кумуляціями к рбон тів перев жно у дифузній формі, рідше - у формі вицвітів. нтенсивне 3 к рбон чення профілю чорноземів опідзолених призвело до руйнув ння горіхув тої структури перехідних горизонтів, їхнього розпушення, кумуляції к рбон тів. цими т іншими морфологічними пок зник ми чорноземи регр дов ні ок льського п см суттєво подібні до чорноземів типових неглибоких. ля їхнього ост точного кл сифік ційного розмежув ння необхідні д ні спеці льних н лізів, зокрем в лового хімічного.

високих, добре дренов них вододіл х орчинського п см , що приляг ють до першої н дз пл вної тер си хідного угу, т кож домінують опідзолені чорноземи. відміну від н логів ок льського п см, вони м ють менш вир зні морфологічні озн ки 3 к рбон чення профілю 3 х р ктерними для цього процесу морфологічними н слідк ми (руйнув ння горіхув тої структури, розпушення грунту, кумуляція к рбон тів), вир зніше помітн кремнеземист присипк т сліди ілювіюв ння глинистого м тері лу. е зумовлено не тільки геоморфологічними, й літологічними особливостями території. окривні лесоподібні суглинки цієї території м ють більшу потужність і глибше підстелені елювієм крейдяно-мергельних порід. нтенсивність регр д ційних процесів у чорнозем х м $€$ т кож природно-господ рську скл дову. им більш трив лість сільськогоспод рського використ ння грунтів 3 н явності в м теринській (підстильній) породі зн чних к рбон тних кумуляцій, з умови дост тньої кількості оп дів і перм нентної зміни н пряму циркуляції грунтової вологи 3 періодом короткоч сного висих ння грунту до вологості в'янення, тим інтенсивніше виявляється процес $3 \mathrm{~K}$ рбон чення чорноземів. більшення площ регр дов них грунтів у скл ді грунтового покриву хідноукр їнського кр ю є головною тенденцією, після ерозії грунтів, його суч сної грогенної еволюції.

грунтовому покриві центр льної ч стини бузького природного р йону

ок льського п см н полого-Хвилястих міжп смових рівнин х сформув лись неглибокі і середньоглибокі відміни чорноземів типових. ороткий гумусовий горизонт, як і профіль з г лом, відсутність чітко вир женого ілюві льно-к рбон тного 
горизонту з кумуляцією дрібнокрист лічного к льциту у формі псевдоміцелію, є головними морфологічними відмінностями чорноземів типових ок льськоорчинської п смової височини від їхніх подільських н логів [4].

орфологічн будов профілю чорноземів типових середньоглибоких м логумусних глеюв тих грубопилув то-легкосуглинкових н лесоподібних суглинк х ок льського п см предст влен розрізом вирк -2 , 3 кл деним 32 км н 3 хід від сф льтового з воду містечк вирк ок льського р-ну ьвівської обл. езорельєф рівн поверхня широкого вододільного пл то з численними мікрозниженнями. либин з кип ння - з 59 см (несуцільне, сл бке). либше 70 см - з кип ння суцільне, сильне. умусовий горизонт з дрібногрудкув то-зернистою структурою, потужністю $79 \mathrm{cм}$. рбон тні кумуляції перев жно в дифузній формі. глибиною вони переходять у форму псевдоміцелію і дрібних жур вчиків (79-100 см). профілі нем будь-яких видимих озн к формув ння ілюві льно-к рбон тного горизонту. ижній перехідний горизонт сильно кротовинний з озн к ми сезонного перезволоження у формі дрібних вохристих плям, з лізисто-м нг нових бобовин, крихких витягнутих конкрецій. орфологічних озн к профільного перерозподілу глинистої пл зми нем .

орноземні грунти ок льсько- орчинської п смової височини приурочені не тільки до високих вододільних м сивів і схилів. они покрив ють більшу ч стину лесових тер с хідного угу, які предст влені перев жно фр гмент ми першої н дз пл вної тер си, що різким уступом 4-5 м переходить у низьку з болочену 3 пл ву. оверхня тер си вкрит легкими з гр нулометричним скл дом лесоподібними суглинк ми. них сформув лись перев жно чорноземи типові глибокі й н дглибокі м логумусні у комплексі з лучно-чорноземними і лучними грунт ми.

орфологічн будов профілю чорноземів типових н дглибоких предст влен розрізом вишень $-1,3$ кл деним н рівній поверхні полотн тер си, н відст ні 450 м південніше від с. вишень ок льського р-ну ьвівської обл. ідст нь від розрізу до крутого уступу тер си - 55 м. ер с добре дренов н . гіддя - рілля.

кип ння від $10 \% \mathrm{HCl}$ з 90 см. ідмінність будови профілю цих грунтів від інших н логів потребує дет льнішого опису їхньої морфології.

op. (0-12 см) - темно-сірий однорідний рівномірний; легкосуглинковий; дрібнозернисто-копрогенної структури; пухкий грубопористий; рясні червоточини, копроліти; перехід помітний з структурою і скл денням.

n/op. (12-76 см) - темно-сірий однорідний рівномірний; легкосуглинковий; дрібно-, середньозернистий; ущільнений, грубопористий; у нижній ч стині кротовинний; рясні крупні червоточини, копроліти, к мери ком х; повсюди рясні корінці; перехід поступовий хвилястий.

$p(k)(76-133$ см) - темно-сірий із бурим відтінком, рівномірний, неоднорідний (зумовлен сильною кротовинністю н 3 г льному темно-сірому фоні); легкосуглинковий; грубозернисто-дрібногоріхув тий; ущільнений, грубопористий; н глибині 12-25 см сл бкі озн ки підплужної підошви; рясні червоточини, копроліти; к рбон ти дифузної форми розсіяні перев жно в дрібноземі кротовин (з кип ння помірне); б г то корінців; перехід поступовий кишенеподібний.

$P(h) k$ (133-190 см) - сильно кротовинний сл бкогумусов ний лес; строк того з 6 рвлення, н з г льному сірув то-п левому фоні рясні сірі кротовини (донизу кротовинність знижується); легкосуглинковий; у кротовин х вир зно дрібногрудкув тий; ущільнений, тонкопористий; к рбон ти суцільним ш ром у дифузній формі; рясні 
кротовини з н повнюв чем від темно-сірого до сірого з 6 рвлення; поодинокі крупні червоточини; перехід поступовий.

$P k$ (190-225 см) - п левого з б рвлення, однорідний, к рбон тний (у дифузній формі), легкосуглинковий лесоподібний суглинок; озн к оглеєння нем .

будовою грунтового профілю (потужний гумусовий горизонт + p) i морфологічними озн к ми (нем ілюві льно-к рбон тного горизонту, озн к профільного і глибинного оглеєння, копрогенн структур ) ці чорноземи суттєво відрізняються не тільки від своїх н логів н вододіл $\mathrm{x}$ і схил $\mathrm{x}$ ок льського п см , й від чорноземів типових одільської височини, де домінують глибокогумусов ні відміни. кби не відсутність озн к оглеєння, їх можн було б кл сифікув ти як лучно-чорноземні грунти.

ир зн невідповідність морфології чорноземів н дглибоких н тер сових місцевостях своїм н лог м н вододіл х і схил х з свідчує, що вони є високо окультуреними грунт ми. евеликі ре ли н логічних 3 морфологією грунтів виявили н першій н дз пл вній тер сі хідного угу в меж х орчинського п см (в околицях c. удин олодимир- олинського р-ну олинської обл., розріз удин -1). гумусовому горизонті н глибині 90-100 см виявлено фр гменти ст рої кер міки, дерев'яних ртеф ктів з вир зними слід ми ручної обробки деревини.

глибоких відмін типових чорноземів гумусовий горизонт $(+p)$ ст новить приблизно половину потужності іхнього гумусового профілю $(\mathrm{H}+\mathrm{Hp}+\mathrm{Ph})$. чорнозем х глибоких першої н дз пл вної тер си гумусовий профіль короткий (130-140 см). ін ф ктично збіг ється з гумусовим горизонтом. ей ф кт свідчить лише про одне у цілинних умов х ці грунти були т кими ж середньоглибокими відмін ми чорноземів, як н вододіл х і схил х. ід впливом трив лого окультурення дод ткового розвитку н був дерновий і супутні йому процеси (елюві льно-гумусовий, вилуговув ння, оструктурення, педотурб ція). умусовий горизонт сформув вся з нижнього перехідного горизонту, одн к глибин прогумусов ності профілю не збільшил сь. он визн чен х р ктером розвитку кореневої системи зл ків, з г льними з п с ми біом си, інтенсивністю кругообігу орг нічного к рбону, гідротермічним режимом грунтів тощо. умов х культурних л ндш фтів усі скл дові біологічного кругообігу, що призводять до формув ння глибоко прогумусов ного профілю чорноземів, $\epsilon$ незрівнянно сл бшими.

профілі чорноземів типових тер сових місцевостей не виявлено жодних морфологічних озн к кислотного руйнув ння їхньої силік тної ч стини і перерозподілу продуктів руйнув ння. оч , зв ж ючи н приуроченість грунтів до низьких тер с, можн припустити, що у порівняно нед лекому минулому ці чорноземи пройшли н півгідроморфну ст дію розвитку і формув ння морфологічного профілю. роцеси грунтоутворення розвив лись синхронно 3 з г льним посиленням дрен жу тер си.

умов х перм нентного з стійно-промивного водного режиму елюві льно-глейовий процес обов'язково призводить до кислотного гідролізу силік тної ч стини профілю 3 винесенням глинисто-з лізистих комплексів униз по профілю. ф зу культурного грунтотворного процесу видимі озн ки руйнув ння мінер льного профілю чорноземів були прихов ні інтенсивною гумусовою кумуляцією.

ез д них в лового хімічного н лізу висловлене вище припущення про культурну скл дову формув ння потужного гумусового горизонту чорноземів глибоких $є$ недост тнім (див. т блицю). 
ловий хімічний скл д чорноземів н лесоподібних суглинк $\mathrm{x}$ ок льсько- орчинської п смової височини

\begin{tabular}{|c|c|c|c|c|c|c|c|c|c|c|c|c|c|c|c|}
\hline \multirow{2}{*}{$\begin{array}{c}\text { либин } \\
\text { відбору } \\
\text { зр зків, } \\
\text { см }\end{array}$} & \multirow[b]{2}{*}{$\begin{array}{r}\text { ігро- } \\
\text { скопічн } \\
\text { вод , \% }\end{array}$} & \multirow{2}{*}{\begin{tabular}{|} 
тр ти \\
під ч с \\
прож - \\
рюв ння, \\
$\%$
\end{tabular}} & \multirow[b]{2}{*}{$\begin{array}{c}{ }^{2} \\
\text { К } \\
\text { н } \\
\text { тів } \\
\%\end{array}$} & \multicolumn{9}{|c|}{ \% н прож рену н в жку } & \multirow[b]{2}{*}{$\frac{\mathrm{SiO}_{2}}{\mathrm{R}_{2} \mathrm{O}_{3}}$} & \multirow[b]{2}{*}{$\frac{\mathrm{SiO}_{2}}{\mathrm{Al}_{2} \mathrm{O}_{3}}$} & \multirow[b]{2}{*}{$\frac{\mathrm{SiO}_{2}}{\mathrm{Fe}_{2} \mathrm{O}_{3}}$} \\
\hline & & & & $\mathrm{SiO}_{2}$ & $\mathrm{Al}_{2} \mathrm{O}_{3}$ & $\mathrm{Fe}_{2} \mathrm{O}_{3}$ & $\mathrm{CaO}$ & $\mathrm{MgO}$ & $\mathrm{K}_{2} \mathrm{O}$ & $\mathrm{Na}_{2} \mathrm{O}$ & $\mathrm{P}_{2} \mathrm{O}_{5}$ & S3 $г$ & & & \\
\hline \multicolumn{16}{|c|}{$\begin{array}{l}\text { орнозем сильнорегр дов ний глеюв тий грубопилув то-легкосуглинковий } \\
\text { ( ок льське пл то, розріз ойсл вичі }-5) \\
\end{array}$} \\
\hline & 1 & 5,05 & нем $\mathrm{E}$ & 82,18 & 9,01 & 2,57 & 1,95 & 0,54 & 2,23 & 0,95 & 0,09 & 0,41 & 13,12 & 51 & 5,27 \\
\hline 25 & & & нем $е$ & 97 & 9,00 & 2,75 & 1,79 & 0,75 & 2,41 & 1,06 & & & 12,96 & & 9,49 \\
\hline $50-60$ & 6 & & 7,35 & 7 & 8,26 & 2,45 & 6,74 & 1,13 & 2,14 & 0,93 & 9 & & 2,27 & 1,59 & 7,14 \\
\hline $90-100$ & 2 & & 31 & 68,50 & 7,37 & 2,35 & 8,80 & 1,25 & 2,04 & \begin{tabular}{|l|}
0,92 \\
\end{tabular} & ,09 & 6 & 3,13 & 5,80 & 7,73 \\
\hline & 1,03 & 0,69 & 8,16 & 68,77 & 7,63 & 2,41 & \begin{tabular}{|l|}
7,77 \\
\end{tabular} & 1,53 & 2,22 & 0,97 & 0,07 & & 12,75 & & 76,09 \\
\hline \multicolumn{16}{|c|}{$\begin{array}{l}\text { орнозем середньоглибокий м логумусний глеюв тий грубопилув то-легкосуглинковий } \\
\text { ( ок льське пл то, розріз }\end{array}$} \\
\hline 0 & 76 & 5,42 & нем $\mathrm{E}$ & 81,77 & 9,42 & 3,01 & 1,06 & 0,54 & 2,24 & 1,07 & 0,08 & 3 & 12,25 & 14,75 & 72,41 \\
\hline 0 & & 4 & $M \in$ & 00 & 9,44 & 2,96 & 1,11 & 0,59 & 2,09 & 8 & 07 & & 2,31 & 4,77 & 73,87 \\
\hline $60-70$ & & & 8 & 1 & 8,96 & 2,87 & 1,01 & 0,73 & 2,24 & 1,15 & 0,08 & 2 & 12,78 & 5,39 & 75,36 \\
\hline 10 & & & 94 & 12 & 7,02 & 2,44 & 10,40 & 1,43 & 1,95 & 0,86 & 0,07 & 4 & 2,71 & 5,53 & 70,08 \\
\hline 150 & 0,98 & 0,00 & 7,25 & $70,62 \mid$ & 7,48 & 2,42 & \begin{tabular}{|l|}
7,30 \\
\end{tabular} & 1,63 & 1,95 & \begin{tabular}{|l|}
0,83 \\
\end{tabular} & 0,06 & 0,32 & 13,31 & 16,05 & 77,82 \\
\hline \multicolumn{16}{|c|}{ 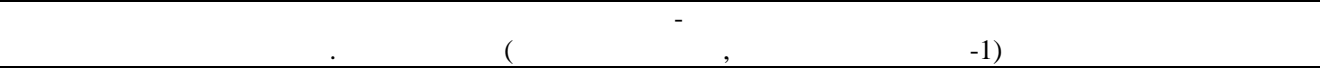 } \\
\hline 20 & 2,23 & 6,69 & нем $\mathrm{E}$ & 84,34 & 6,98 & 2,18 & 1,69 & 0,60 & 1,79 & \begin{tabular}{|l|}
0,88 \\
\end{tabular} & 0,49 & 0,53 & 17,13 & 20,54 & 103,17 \\
\hline & & & нем $є$ & \begin{tabular}{|l|}
84,19 \\
\end{tabular} & 6,79 & 2,18 & 2,60 & 0,33 & 1,69 & 0,84 & 0,79 & & 17,50 & 1,08 & 102,98 \\
\hline $90-100$ & 77 & 3 & 3,50 & 79,34 & 6,94 & 2,47 & 2,75 & 0,52 & 1,97 & 0,88 & 0,95 & 0,50 & 15,84 & 19,43 & 85,66 \\
\hline 160 & & & 2,34 & $81,67 \mid$ & 7,21 & 2,24 & 2,01 & \begin{tabular}{|l|}
0,62 \\
\end{tabular} & 0,99 & 0,89 & 0,36 & 0,27 & 16,07 & 19,26 & 97,23 \\
\hline $210-220$ & 0,79 & 0,70 & 6,92 & 71,34 & 6,68 & 2,04 & \begin{tabular}{|l|}
7,85 \\
\end{tabular} & 1,33 & 1,89 & \begin{tabular}{|l|}
0,95 \\
\end{tabular} & 0,22 & 0,39 & 15,20 & 18,16 & 93,25 \\
\hline \multicolumn{16}{|c|}{$\begin{array}{c}\text { орнозем глибокий м логумусний глеюв тий грубопилув то-легкосуглинковий першої н дз пл вної тер си } \\
\text { p. } \quad \text { хідний } \quad \text { уг ( орчинське пл то, розріз удин }-1)\end{array}$} \\
\hline & & 7,07 & - & 80,96 & 7,87 & 2,31 & \begin{tabular}{|l|}
4,04 \\
\end{tabular} & 0,74 & 1,80 & \begin{tabular}{|l|}
0,62 \\
\end{tabular} & 0,62 & 0,23 & 14,73 & 17,49 & 33,46 \\
\hline $30-40$ & 1,95 & 6,65 & - & 81,27 & 7,98 & 2,40 & 3,52 & 0,78 & 1,87 & \begin{tabular}{|l|}
0,59 \\
\end{tabular} & 0,61 & 0,13 & 14,53 & 17,31 & 90,30 \\
\hline $70-80$ & 1,96 & 5,90 & - & 81,50 & 8,05 & 2,58 & 3,36 & 0,60 & 1,73 & 0,55 & 0,56 & 0,08 & 14,29 & 17,21 & 84,24 \\
\hline $120-130$ & 2,11 & 5,29 & - & 82,40 & 7,87 & 2,26 & 2,80 & 0,76 & 1,70 & 0,54 & 0,58 & 0,04 & 15,04 & 17,80 & 97,23 \\
\hline $0-200$ & 0,89 & 6,54 & - & 77,24 & 7,68 & 2,16 & \begin{tabular}{|l|}
9,09 \\
\end{tabular} & 0,43 & 1,73 & 0,64 & 0,16 & 0,19 & 14,50 & 17,10 & 95,36 \\
\hline
\end{tabular}

в ловому хімічному скл ді досліджув них чорноземів простежено невл стивий їм, особливо чорнозем м типовим, високий вміст оксиду кремнію в гумусовому горизонті (79-84\%). ого вертик льний розподіл м $є$ форму прогресивнокумулятивної кривої з н копиченням у гумусовому горизонті. е свідчить про відносну кумуляцію в ньому стійких до звітрюв ння силік тів і люмосилік тів. підтвердження висловленого припущення в мінер логічному скл ді мулув тої фр кції (ч стки розміром <1 мкм) чорноземів опідзолених і типових оділля $\mathrm{i}$ ередк рп ття ми рентгеногр фічно з фіксув ли велику кількість високодисперсних кл стогенних мінер лів (кв рц, -польові шп ти, пл гіокл зи) [3].

явність н трієвих пл гіокл зів підтверджен великою кількістю оксиду н трію (0,56-1,08\%). ричому в чорнозем х ок льського п см їх помітно більше, ніж у грунт х орчинського п см . ричин цього, ймовірно, прихов н в різній генетичній природі лесоподібних суглинків двох регіонів.

исокий вміст в лового к лію (1,73-2,41\%) свідчить про домінув ння в мінер логічному скл ді мулистої фр кції чорноземів зміш нош рув тих слюд -смектитових мінер лів і гідрослюд. ричому кількість оксиду к лію дещо знижується з глибиною, 
що узгоджується з д ними мінер логічного н лізу мулистої фр кції чорноземів хідноукр їнського кр ю [3].

ертик льний розподіл оксидів люмінію і феруму підтверджує різну генетичну природу чорноземів опідзолених і типових. більшення кількості оксидів силіцію й люмінію у верхній ч стині профілю більшості грунтових розрізів свідчить про високу уч сть кремнезему й люмінієвих діокт едричних гідрослюд у мінер логічному скл ді досліджув них грунтів. опідзолених грунт х кількість оксиду феруму збільшується в середній ч стині профілю. ільш рівномірний х р ктер вертик льного розподілу цього хімічного елемент прит м нний регр дов ним чорнозем м. е цілком зрозуміло, дже інтенсивне 3 к рбон чення профілю блокує процес лесив жу з низхідним рухом мінер льних колоїдних розчинів, зумовлюючи їхню ко гуляцію у меж х гумусового горизонту.

типових чорнозем х н вододіл $\mathrm{x}$ і схил х вертик льний розподіл оксидів феруму м $€$ вир зний кумулятивний тип (див. т блицю). нш поведінк цього оксиду в чорнозем х типових глибоких н низьких тер с х. них, як і в опідзолених н лог х, м ксимум вмісту оксиду феруму прип д $є$ н перехідний гумусовий горизонт. мовірно, т кий х р ктер мінер льного профілю м є реліктове, п леогідроморфне походження. дже у минулому чорноземи н тер с х пройшли н півгідроморфну ст дію еволюції з інтенсивним розвитком елюві льно-глейового процесу, н слідком якого є незб л нсов ні втр ти феруму.

міст оксидів фосфору $(0,56-0,95 \%)$ і сульфуру $(0,13-0,53 \%)$ в чорнозем х типових тер сових місцевостей у кільк $\mathrm{p}$ зів вищий, ніж у грунт х вододілів і схилів. е 3 йвий р з свідчить про їхню кумуляцію у процесі трив лого сільськогоспод рського окультурення земель. ричому головним резервом його н копичення $є$ мулист фр кція чорноземів [3]. е чи не основний док 3 культурної скл дової в еволюції чорноземів першої н дз пл вної тер си хідного угу в меж $\mathrm{x}$ ок льськоорчинської п смової височини.

уже пок зовими є д ні молярних співвідношень $\mathrm{SiO}_{2}$ до півтор оксидів у сумі $\left(\mathrm{Al}_{2} \mathrm{O}_{3}+\mathrm{R}_{2} \mathrm{O}_{3}\right)$ і кожного зокрем . скільки вн слідок опідзолення з крист лічної гр тки мінер лів мобілізується перев жно ферум, то с ме співвідношення $\mathrm{SiO}_{2} / \mathrm{Fe}_{2} \mathrm{O}_{3}$ є н йбільш прид тним для генетичного н лізу грунтів. гумусовому горизонті чорноземів опідзолених регр дов них цей пок зник розширюється $(79,49-91,36)$, в перехідному гумусовому - н вп ки, звужується $(77,14-78,93)$. е свідчить про відносне н копичення у верхній ч стині профілю кремнезему і збіднення їі н глинисті мінер ли і сполуки феруму. тож ці чорноземи у минулому пройшли ст дії вилуговув ння, інтенсивного опідзолення і лесив жу. роцес 3 к рбон чення профілю чорноземів регр дов них, що н кл вся н вже сформов ний мінер льний профіль грунтів, н слідк ми не може з м скув ти суттєві зміни їхньої силік тної ч стини.

чорнозем х типових н вододіл $\mathrm{x}$ і схил $\mathrm{x}$ x р ктер молярних співвідношень $\mathrm{SiO}_{2} / \mathrm{Fe}_{2} \mathrm{O}_{3}$ рівномірніший $(72,41-77,82)$ з тенденцією до звуження в гумусовокумулятивному горизонті. е з свідчує, що в втоморфних умов х ці чорноземи не проходили ст дії кислотного гідролізу і перерозподілу мінер льної речовини в минулому. они є моногенетичними грунт ми з тенденцією до н копичення сі літної глини (внутрішньогрунтове оглинення in situ) у верхній ч стині профілю.

тер сових місцевостях чорноземи типові глибокі м ють вир зні морфологічні озн ки цього ф ці льного підтипу чорноземів. дн к результ ти в лового хімічного н лізу розкрив ють їхню спр вжню генетичну природу. ище з зн чено, що деякі 
елементи морфологічного профілю цих грунтів (м лопотужний гумусовий профіль, відсутність ілюві льно-к рбон тного горизонту з рясними кумуляціями видимих форм к рбон тів, копрогенн структур , високий вміст оксидів фосфору і сульфуру) свідч ть про х р ктер еволюційних змін н ст дії інтенсивного використ ння грунтів. н чне розширення пок зник молярних співвідношень $\mathrm{SiO}_{2} / \mathrm{Fe}_{2} \mathrm{O}_{3}$ в гумусовокумулятивному горизонті чорноземів глибоких до 102,98-103,17 з різким звуженням його $(85,66-97,23)$ в перехідному гумусовому горизонті свідчить про ст дію інтенсивного кислотного руйнув ння силік тної ч стини грунтів (розріз вишень -1). огляду н приуроченість цих чорноземів до тер си, можн зробити висновок, що перерозподіл основних оксидів відбув вся вн слідок елюві льно-глейового процесу ще н р нній ст дії формув ння чорноземів. оч з перечити можливість опідзолення профілю у минулому т кож не можн .

тже, чорноземи ок льсько- орчинської п смової височини з зн ли скл дних еволюційних змін у пізньому голоцені. і зміни з чепили всі без винятку грунти, зумовивши різний х р ктер тр нсформ ції їхнього морфологічного, орг нічного і мінер льного профілю. ділянк х вододілів і схилів основним мех нізмом грогенної еволюції чорноземів є процеси з к рбон чення профілю, тр нсформ ції їхніх з г льних фізичних і фізико-хімічних вл стивостей. они н стільки сильно змінили профіль опідзолених чорноземів, н близивши їх до типових неглибоких відмін, що тільки метод ми мікроморфологічного, в лового хімічного і мінер логічного н лізів можн однозн чно ідентифікув ти їхню спр вжню природу.

добре дренов них тер с х, де чорноземи використовують н йдовше, нтропогенн скл дов грунтоутворення дуже вир зн . он виявляється в глибоких змін х гумусового профілю чорноземів глибоких і н дглибоких, який повністю з ву льовує спр вжній, елюві льно-ілюві льний тип будови їхньої силік тної ч стини. оєдн ння морфологічного й н літичного методів дослідження чорноземів д $є$ змогу виявити прихов ні риси їхнього генетичного профілю, з'ясув ти спр вжню природу грунту, х р ктер і спрямов ність його пізньоголоценової еволюції.

перспективі сітк опорних розрізів чорноземів, приурочених до різних елементів і форм рельєфу й для яких є д ні в лового хімічного (мінер логічного, мікроморфологічного) н лізу, д сть змогу н уково обгрунтув ти х р ктер ст новлення, історію розвитку, умови функціонув ння і еволюцію чорноземів хідноукр їнського кр ю.

\section{СПИСОК ВИКОРИСТАНОЇ ЛІТЕРАТУРИ}

1. ндрущенко . . рунти з хідних обл стей

$$
\text { / . . ндрущенко. - ьвів; }
$$
убляни : ільн кр їн , 1970.- .1.-184 с

2. ленчук . . рунти ьвівської обл сті / . . ленчук, . . иколин. - ьвів меняр, 1969. - 84 с.

3. піш . . роцеси диференці ції мінер льної речовини чорноземів смового обужжя / гор піш // еогр фічн н ук і пр ктик : виклики епохи : м тері ли міжн р. н ук. конф., присвяченої 130-річчю геогр фії у ьвівському університеті (м. ьвів, 16-18 тр вня 2013 р.) / [ ідп. ред ктори: доц. . . іл нюк, доц. . . в нов]. 3 т. - ьвів : ид вничий центр імені в н 2013. - . 2. - .279-283. 
4. піш . . роблеми генези чорноземів личини / . піш, . озняк // існик ьвів. ун-ту. ер. геогр. - 2010. - ип. 38. - . 271-280.

5. очвы / . . ерн ндер, . . одлин, . . мбур, . . корин . иев; рьков : осизд т. сельхоз. лит-ры, 1951. - 320 с.

6. рирод ьвівської обл сті / [3 ред. . . еренчук ]. - ьвів : ид-во ьвів. ун-ту, 1972. -152 c.

7. шевлоцький - . рунти ок льського п см і їх грогенн тр нсформ ція / . . шевлоцький, . . ськевич. - ьвів : ид вничий центр ім. . p нк , 2002. $-180 \mathrm{c}$.

8. утковский . . го- п дный кр й. опулярные естественно-исторические и геогр фические очерки / . . у утковский. - иев, 1893. - ып. 1. - 178 с.

9. ередіїв . рунти / . ередіїв // еогр фія укр їнських і сумежних земель / 3 ред. . убійович . - ьвів : кр їнський вид вничий інститут у ьвові, 1938. . 1. г льн геогр фія. - . 122-131.

10. Buber L. Die galizisch-podolische Schwarzerde, ihre Entstehung und naturliche Beschaffenheit und die gegenwartigen landwirtschaftichen Betriebsverhaltnisse des Nordostens dieser Bodenzone Galiziens / Leopold Buber. - Berlin, 1910. - 205 s.

m ття:н дійшл до ред киї̈ 14.05.2013

доопр цьов н 30.05 .2013

прийнят до друку 17.06.2013

\title{
TOTAL CHEMICAL COMPOSITION OF CHORNOZEMS OF SOCAL-TORTCHIN RANGE UPLAND
}

\author{
Igor Papish \\ Ivan Franko National University of Lviv, \\ P. Doroshenko St., 41, UA - 79000, Lviv, Ukraine
}

The results are given on total chemical composition of podzolic and typical chernozems of the Socal-Tortchin range upland. The geographical features of forming of morphological profile of chernozems of Volyn upland are educed. Connection is shown between different genetic subtypes of chernozems and chemical composition them silicate part. The cultural constituent of soil formation is educed in forming of morphological profile of deep chernozems on terrace localities of Volyn Pobuzia.

Key words: chernozems, total chemical composition, structure of the soil profile, morphological signs, cultural evolution of soils. 


\author{
горь ІІиш \\ ввовский н цион льный университет имени в н р нко, \\ ул. . орошенко, 41, 79000, г. ьвов, кр ин
}

риведено д нные в лового химического сост в черноземов оподзоленных и типичных ок льско- орчинской грядовой возвышенности. ыявлено геогр фические особенности формиров ния морфологического профиля черноземов олынской возвышенности. ок 3 но связь между р зными генетическими подтип ми черноземов и химическим сост вом их силик тной ч сти. ыявлено культурную сост вляющую почвообр зов ния в формиров нии морфологического профиля черноземов глубоких терр совых местностей олынского обужья.

лючевые слов : чернозем, в ловой химический сост в, строение почвенного профиля, морфологические призн ки, культурн я эволюция почв. 